\title{
Biotic Factors Affecting Expression of the 2,4-Diacetylphloroglucinol Biosynthesis Gene phlA in Pseudomonas fluorescens Biocontrol Strain CHA0 in the Rhizosphere
}

\author{
R. Notz, M. Maurhofer, U. Schnider-Keel, B. Duffy, D. Haas, and G. Défago
}

First, second, and sixth authors: Institute of Plant Sciences, Phytopathology group, Swiss Federal Institute of Technology, CH-8092 Zürich; third and fifth authors: Laboratoire de Biologie Microbienne, Université de Lausanne, CH-1015 Lausanne, Switzerland; and fourth author:

U.S. Department of Agriculture, Agricultural Research Service, Food Safety and Health Research Unit, Albany, CA 94710. Accepted for publication 17 May 2001.

\begin{abstract}
Notz, R., Maurhofer, M., Schnider-Keel, U., Duffy, B., Haas, D., and Défago, G. 2001. Biotic factors affecting expression of the 2,4-diacetylphloroglucinol biosynthesis gene phlA in Pseudomonas fluorescens biocontrol strain CHA0 in the rhizosphere. Phytopathology 91:873-881.

Production of the polyketide antimicrobial metabolite 2,4-diacetylphloroglucinol (DAPG) is a key factor in the biocontrol activity of Pseudomonas fluorescens CHA0. Strain CHA0 carrying a translational $p h l A^{\prime}$-'lacZ fusion was used to monitor expression of the $p h l$ biosynthetic genes in vitro and in the rhizosphere. Expression of the reporter gene accurately reflected actual production of DAPG in vitro and in planta as determined by direct extraction of the antimicrobial compound. In a gnotobiotic system containing a clay and sand-based artificial soil, reporter gene expression was significantly greater in the rhizospheres of two monocots (maize and wheat) compared with gene expression in the

Significant differences were found among six additional maize cultivars tested under gnotobiotic conditions. There was no difference between transgenic maize expressing the Bacillus thuringiensis insecticidal gene $c r y l A b$ and the near-isogenic parent line. Plant age had a significant impact on gene expression. Using maize as a model, expression of the phlA'-'lacZ reporter gene peaked at $24 \mathrm{~h}$ after planting of pregerminated seedlings, and dropped to a fourth of that value within $48 \mathrm{~h}$, remaining at that level throughout 22 days of plant growth. Root infection by Pythium ultimum stimulated bacterial gene expression on both cucumber and maize, and this was independent of differences in rhizosphere colonization on these host plants. To our knowledge, this is the first comprehensive evaluation of how biotic factors that commonly confront bacterial inoculants in agricultural systems (host genotype, host age, and pathogen infection) modulate the expression of key biocontrol genes for disease suppression.
\end{abstract} rhizospheres of two dicots (bean and cucumber). We observed this host genotype effect on bacterial gene expression also at the level of cultivars.
Additional keywords: Cucumis sativus, transgenic corn, Zea mays.
Certain root-associated bacteria have the ability to reduce the severity of diseases caused by soilborne fungal pathogens and to increase plant yield under laboratory and greenhouse conditions $(8,26)$. In commercial settings and field trials, however, inconsistent performance from site to site and from year to year tends to be the disappointing reality (49). Concerns about performance reliability are a major impediment to large-scale application of bacterial-based biocontrol products.

Understanding the sources of variability is key to overcoming this obstacle. Recent evidence indicates that at least part of this variability can be attributed to variations in environmental conditions, abiotic and biotic, that confront bacterial inoculants in the rhizosphere. Many of the same factors long known to influence plant pathogens (12), are now found to affect the performance of biocontrol agents but in different ways. For example, there is a clear link between abiotic soil factors (e.g., $\mathrm{pH}$ and mineral concentrations) and the variability in biocontrol activity of both fungal and bacterial inoculants against root diseases $(11,35,36)$. Soil factors, particularly clay quality, are important in development of disease suppressive soils containing natural antagonists (22). Host genotype affects pathogens in specific and nonspecific ways. Genotype also affects root colonization and biocontrol

Corresponding author: G. Défago

E-mail address: genevieve.defago@ipw.agrl.ethz.ch

Publication no. P-2001-0622-01R

(C) 2001 The American Phytopathological Society activity of bacterial strains, with recent evidence that host traits favorable for biological control are quantitatively inherited (46). Because a primary mechanism of disease suppression available to these bacteria is antibiosis (49), it is thought that variable performance might result from variation in production of antimicrobial compounds on different hosts.

The polyketide antimicrobial metabolite, 2,4-diacetylphloroglucinol (DAPG), has emerged as one of the most important antimicrobial compounds produced by biocontrol strains of Pseudomonas fluorescens $(21,49)$. Reporter genes are an attractive approach to monitor bacterial gene expression, with high sensitivity and relatively little technical constraints. We have developed a DAPG reporter gene for quantitatively monitoring biosynthesis in culture (43). Using this reporter gene, which consists of a lacZ translational fusion to the structural gene phlA, which is the promoter-proximal gene in the phlACBDE cluster (1), we have shown that DAPG biosynthesis is strongly dependent on cell density and positively auto-regulated by DAPG in vitro (43). The vector plasmid used, pME6010, has approximately six copies per chromosome and is maintained and stable in Pseudomonas fluorescens in the absence of antibiotic selection (19). The objective of the current study was to use this reporter gene to examine the effect of biotic factors on DAPG production in situ. Specifically, we evaluated the influence of host species and cultivar on DAPG gene expression in the rhizosphere and related this to biocontrol activity. We used the reporter gene to evaluate the effects of other biotic factors that have previously received less attention such as host age and host health when attacked by root-pathogenic fungi. 


\section{MATERIALS AND METHODS}

Microorganisms, plants, and culture conditions. Pseudomonas fluorescens CHAO (48) and a derivative harboring plasmid pME6259 (43) were routinely cultivated on agar plates of King's B medium (KB) (23) and in Luria-Bertani broth (LB) (41) at $27^{\circ} \mathrm{C}$, unless otherwise mentioned. Strain $\mathrm{CHA} 0 /$ pME6259 was grown in the presence of tetracycline $(125 \mu \mathrm{g} / \mathrm{ml})$.

Pythium ultimum 67-1 (obtained from Allelix Agriculture, Mississauga, ON, Canada) was cultured on $1.5 \%$ malt agar plates (Difco Laboratories, Detroit) at $20^{\circ} \mathrm{C}$ for 7 days. For disease suppression assays, a $0.7-\mathrm{cm}$ plug of an actively growing Pythium ultimum agar culture was placed in a petri dish containing $25 \mathrm{~g}$ of autoclaved millet seeds (Biofarm, Kleindietwil, Switzerland) and $10 \mathrm{ml}$ of sterilized double-distilled water. After 7 days of incubation at $20^{\circ} \mathrm{C}$ in darkness, the mycelium-covered millet was sieved. Particles of 1-mm diameter were used to infest soil. Plant species and cultivars used were bush bean (Phaseolus sativus cv. Saxa), cucumber (Cucumis sativus cv. Chinesische Schlange), winter wheat (Triticum aestivum cv. Arina), and maize (Zea mays cvs. Maïs Silex 170, Antares, Corso, Magister, Max 88, N4660, and N4660 Bt). 'Max 88' (event 176) and 'N4660 Bt' (event 11) are transgenic maize hybrids carrying the $c r y l A b$ gene for biosynthesis of abbreviated Bacillus thuringiensis insecticidal toxin, and the other cultivars are silage varieties. Seeds were surface-disinfected for $15 \mathrm{~min}$ in $7 \%$ ( vol/vol) sodium hypochlorite, followed by $10 \mathrm{~min}$ in $10 \%$ (vol/vol) $\mathrm{H}_{2} \mathrm{O}_{2}$, and thoroughly rinsed with sterile double-distilled water. Seeds were pregerminated for 3 days on $0.85 \%$ water agar at $24^{\circ} \mathrm{C}$ in darkness.

Assays of DAPG production and phlA'-'lacZ expression in vitro. Strain $\mathrm{CHA0}$ and its derivative $\mathrm{CHA0/pME6259}$ were grown in 500-ml Erlenmeyer flasks sealed with cotton wool stoppers containing $200 \mathrm{ml}$ of $\mathrm{KB}$ medium without tetracycline. Media were inoculated with $100 \mu \mathrm{l}$ of an overnight LB culture and incubated at $27^{\circ} \mathrm{C}$ with shaking at $160 \mathrm{rpm}$. Samples were taken over a period of 7 days. Bacterial growth was determined by measuring the optical density (OD) at $600 \mathrm{~nm}$, after having established by dilution plating the correlation with $\mathrm{CFU}$. $\beta$-Galactosidase expression of $p h l A^{\prime}-{ }^{\prime} l a c Z$ on plasmid pME6259 was quantified according to Miller (32).

Production of DAPG was quantified using high-performance liquid chromatography (HPLC) as previously described $(10,30)$. Aliquots of bacterial cultures $(10 \mathrm{ml})$ were acidified with $2 \mathrm{M} \mathrm{HCl}$ to $\mathrm{pH} 2$ to 3 , mixed with $10 \mathrm{ml}$ of ethyl acetate, and shaken vigorously. The organic phase was separated from the aqueous phase by filtering through silicon-coated filter paper (MachereyNagel, Düren, Germany) and dried in a vacuum centrifuge (HETOVAC; Heto Lab Equipment, Allerød, Denmark). The residue was dissolved in $1 \mathrm{ml}$ of methanol and analyzed by a liquid chromatograph equipped with a diode-array detector (Hewlett Packard 1090; Hewlett-Packard Co., Palo Alto, CA) and a column $(100 \times 4 \mathrm{~mm})$ packed with Nucleosil 120-5-C18 (MachereyNagel, Düren, Germany).

Assay for gene expression in the rhizosphere. The influence of several biotic environmental factors (i.e., plant species, maize cultivar, plant age, and the presence of the pathogen Pythium ultimum) on the expression of the phlA' ${ }^{\prime}$ lac $Z$ reporter gene was monitored under gnotobiotic conditions. Plants inoculated with bacteria were grown in flasks containing an artificial soil comprised of vermiculite and quartz sand of different particle sizes (22). The artificial soil was moistened with double-distilled water $(10 \%, \mathrm{wt} / \mathrm{wt})$ and autoclaved in flasks before planting.

For experiments comparing different plant species and maize plant age, Erlenmeyer flasks (300 ml) containing $75 \mathrm{~g}$ of artificial soil were closed with cotton wool stoppers, autoclaved at $121^{\circ} \mathrm{C}$ for $30 \mathrm{~min}$, and amended with $10 \mathrm{ml}$ of modified Knop's nutrient solution (22). Overnight LB cultures of CHA0/pME6259 were assayed for $\beta$-galactosidase activity, washed with $0.9 \% \mathrm{NaCl}$ solution, and diluted to an $\mathrm{OD}_{600}$ of 0.0125 to give a final concentration of $10^{7} \mathrm{CFU} / \mathrm{ml}$. The seeds were pregerminated as described previously. Plant seedlings were soaked in the bacterial suspension for $1 \mathrm{~h}$. Thereafter, five seedlings were transferred to each flask and covered with soil. Control flasks were planted with seedlings inoculated with wild-type strain CHA0. The flasks were incubated in growth chambers with 16 -h light at $18^{\circ} \mathrm{C}\left(160 \mu \mathrm{E} / \mathrm{m}^{2} / \mathrm{s}\right)$ followed by 8 -h darkness at $13^{\circ} \mathrm{C}$. In the experiment comparing plant species, samples were taken at 3,5, and 10 days after planting. In the experiment evaluating plant age, samples were taken at $3 \mathrm{~h}$ and $1,3,5,7,10,14$, and 21 days after planting. In both experiments, treatments consisted of four replicate flasks arranged in a completely randomized design. In the experiment evaluating maize cultivar effects on gene expression in the rhizosphere, conditions were as previously described, except that seedlings were grown in 1-liter flasks with $300 \mathrm{~g}$ of artificial soil, watered with $30 \mathrm{ml}$ of Knop's solution, and sampled at day 6 . Treatments consisted of four flasks arranged in a randomized complete block design.

In the experiment examining the effect of the pathogen on gene expression, 1-liter Erlenmeyer flasks were filled with $300 \mathrm{~g}$ of artificial soil, plugged, and autoclaved as described previously. Sieved millet powder completely colonized by Pythium ultimum was mixed into the soil at a rate of $10 \mathrm{mg}$ for cucumber and $100 \mathrm{mg}$ for maize. Control flasks without the pathogen received the same amount of autoclaved millet powder. Thirty milliliters of Knop's nutrient solution was added. Cucumber and maize seedlings were pregerminated, inoculated with bacteria, and planted. After 7 days in the growth chamber under the same conditions described previously, disease severity, root colonization, and $\beta$ galactosidase activity were determined.

Disease severity rating, root colonization, and $\beta$-galactosidase activity. In the absence of quantifiable visible lesions with Pythium ultimum on the two host plants tested, we estimated disease severity based on reduction in seedling emergence and reduction of plant weight $(24,31)$. Plants were removed from the flasks and gently shaken to discard loosely adhering soil. Roots with rhizosphere soil were placed in sterile flasks with saline solution and mechanically shaken for $5 \mathrm{~min}$ at $300 \mathrm{rpm}$. Bacterial root colonization was determined from the resulting suspension by plating serial dilutions on appropriate agar media (22). Our washing method recovered $97.1 \pm 1.3 \%$ of the bacteria from wheat roots. Recovery efficiency was not increased by a longer initial wash $(30 \mathrm{~min})$ or vortexing (15 or $60 \mathrm{~s}$ ) (data not shown). $\beta$ Galactosidase activity was measured with $200 \mu \mathrm{l}$ of the root suspension. Control treatments of plants inoculated with wild-type strain CHA0 were used to subtract background activity from calculations. Plants were washed with tap water, blotted dry with paper tissues, and weighed. $\beta$-Galactosidase activities were expressed as units per $10^{8} \mathrm{CFU}$. Unit values were calculated according to Miller (32) with the following formula: $1,000 \times \mathrm{OD}_{420} /$ time $($ min $) \times$ sample volume $(\mathrm{ml})=$ units of $\beta$-galactosidase .

Plasmid stability and inoculum activity. Stability of plasmid pME6259 was determined by replica plating onto KB agar supplemented with tetracycline $\left(125 \mu \mathrm{g} \mathrm{ml}^{-1}\right)$. After $48 \mathrm{~h}$ at $27^{\circ} \mathrm{C}$, the percentage of tetracycline-resistant colonies indicative of pME6259 was evaluated. $\beta$-Galactosidase activity of the bacterial inoculum used for in vitro and in situ experiments was determined.

Extraction and quantification of DAPG produced in the rhizosphere. To compare in situ $\beta$-galactosidase activity with in situ production of DAPG, pregerminated maize and cucumber seedlings were inoculated with Pseudomonas fluorescens CHA0/ pME6259 and grown in artificial soil under gnotobiotic conditions. Control treatments consisted of maize and cucumber plants grown without bacteria. Experiments with maize consisted of 150 plants, and experiments with cucumber consisted of 230 plants. Each flask contained five plants. After 10 days of growth, plants were removed from the flasks. Plants from four flasks per treatment $(n=$ $20)$ were weighed and assessed for $\beta$-galactosidase activity and 
root colonization. All remaining plants were used for direct extraction of DAPG (maize, $n=130$; cucumber, $n=210$ ). One hundred-gram portions of roots with rhizosphere soil were mixed with $250-\mathrm{ml}$ volumes of ethyl acetate, acidified to $\mathrm{pH} 2$ with $2 \mathrm{M}$ $\mathrm{HCl}$, and vigorously shaken for $30 \mathrm{~min}$ at $200 \mathrm{rpm}$. Soil and roots were removed by passing the extraction solution through hydrophobic filter paper (Macherey-Nagel, Düren, Germany). Roots and shoots were washed and weighed. The extract solvent phase was evaporated in vacuo and the residue redissolved in $1 \mathrm{ml}$ of methanol. Extracts were analyzed for DAPG quantity by HPLC with a Nucleosil packed column $(250 \times 4 \mathrm{~mm})$ (Macherey-Nagel, Düren, Germany) as described in Keel et al. (21). The recovery efficiency for this procedure was approximately $45 \%$, estimated by adding synthetic DAPG to gnotobiotic soil without bacteria or plants (data not shown).

Statistics. All experiments were repeated two to three times. For each experiment, data from all the trials were first analyzed for a trial-treatment interaction with analysis of variance using either Systat version 9.0 (Systat Inc., Evanston, IL) or PC SAS version 8.1 (SAS Institute, Cary, NC). When no trial-treatment interaction was detected, data were pooled for final analysis. Otherwise, data are presented for individual trials. In multifactorial experiments (e.g., effect of plant species at different growth ages), significant interactions were further analyzed by examining the influence of each level of the main effects (e.g., maize at each of three ages). When appropriate, means were separated with Fisher's protected $(P=0.05)$ least significant difference (LSD) test.

\section{RESULTS}

Plasmid stability and residual $\beta$-galactosidase activity in inoculum. In the in vitro experiments, retention of the reporter plasmid pME6259 by strain CHA0 was $98.8 \pm 0.9 \%$ after 20 generations of growth in LB broth. In the in planta experiments, retention was $99.3 \pm 1.0 \%$, based on the viable bacteria reisolated from the rhizosphere that grew on antibiotic-amended agar. The reporter gene was expressed at low levels when strain $\mathrm{CHA0/}$ pME6259 was grown in LB, which was used for inoculum preparation. $\beta$-Galactosidase activity was less than 3 units per $10^{8} \mathrm{CFU}$ detected in the overnight cultures of Pseudomonas fluorescens CHA0/pME6259 used to inoculate either KB broth cultures or pregerminated plantlets. Thus, the levels of activity that were detected reflect gene activity during the course of the experiments.

Correlation of $p h l A^{\prime}-$ lac reporter gene expression with DAPG production in vitro. Expression levels of the plasmidborne translational $p h l A^{\prime}-{ }^{\prime} l a c Z$ gene fusion directly paralleled production of DAPG during growth of Pseudomonas fluorescens CHA0/pME6259 in KB broth (Fig. 1). Reporter gene expression, determined as units of $\beta$-galactosidase activity, and accumulation of DAPG in media were first detected during mid-exponential growth phase and peaked during late exponential growth phase. The maximum concentration of DAPG recovered from cultures was $10.3 \mathrm{nmol}$ per $10^{8} \mathrm{CFU}$ after $25 \mathrm{~h}$ growth, and the maximum $\beta$-galactosidase activity was 5,600 units per $10^{8} \mathrm{CFU}$ at $22 \mathrm{~h}$ growth. Thereafter, DAPG concentrations steadily declined because of degradation by the bacterium (Fig. 1).

Influence of plant species on phlA expression. There was a dramatic difference in the level of reporter gene expression in the rhizospheres of the four crop species tested $(P \leq 0.0001)$ (Fig. 2). Almost all of this difference could be split between monocots and dicots. When maize and wheat were compared, levels of gene expression were similar (Fig. 2A to C). For example, at 3 days after planting, $\beta$-galactosidase activity was approximately 100 units per $10^{8} \mathrm{CFU}$ on maize and 90 units per $10^{8} \mathrm{CFU}$ on wheat. This was approximately fourfold higher than the level of gene expression measured on the two dicots, which was approximately 25 units per $10^{8} \mathrm{CFU}$ for either species (Fig. 2). There was no difference, though, between bean and cucumber.
Influence of plant age on phlA expression. In one experiment previously described, i.e., in the maize rhizosphere, there was a significant influence of plant age on reporter gene expression $(P=$ $0.009)$. For the other three species, no significant age effect was observed $(P=0.561,0.089$, and 0.447 for wheat, bean, and cucumber, respectively). In maize, $\beta$-galactosidase activity doubled from approximately 100 units per $10^{8} \mathrm{CFU}$ at 3 and 5 days to approximately 210 units per $10^{8} \mathrm{CFU}$ at 10 days after planting (Fig. 2). Not surprisingly, the difference between maize and the other plant species was also greatest at 10 days.

Because the effect of plant age was most evident with maize, we examined $\mathrm{CHA} 0 / \mathrm{pME} 6259$ gene expression on this species over a longer growth period. Interestingly, although gene expression levels observed after seedling emergence were similar to those observed in the previous experiment (approximately 100 units per $10^{8} \mathrm{CFU}$ ), the greatest effect of age occurred even earlier in plant growth. There was a rapid increase in $\beta$-galactosidase activity early in growth that peaked at over 400 units per $10^{8} \mathrm{CFU}$ at 1 day after planting (Fig. 3). Then activity just as rapidly declined to
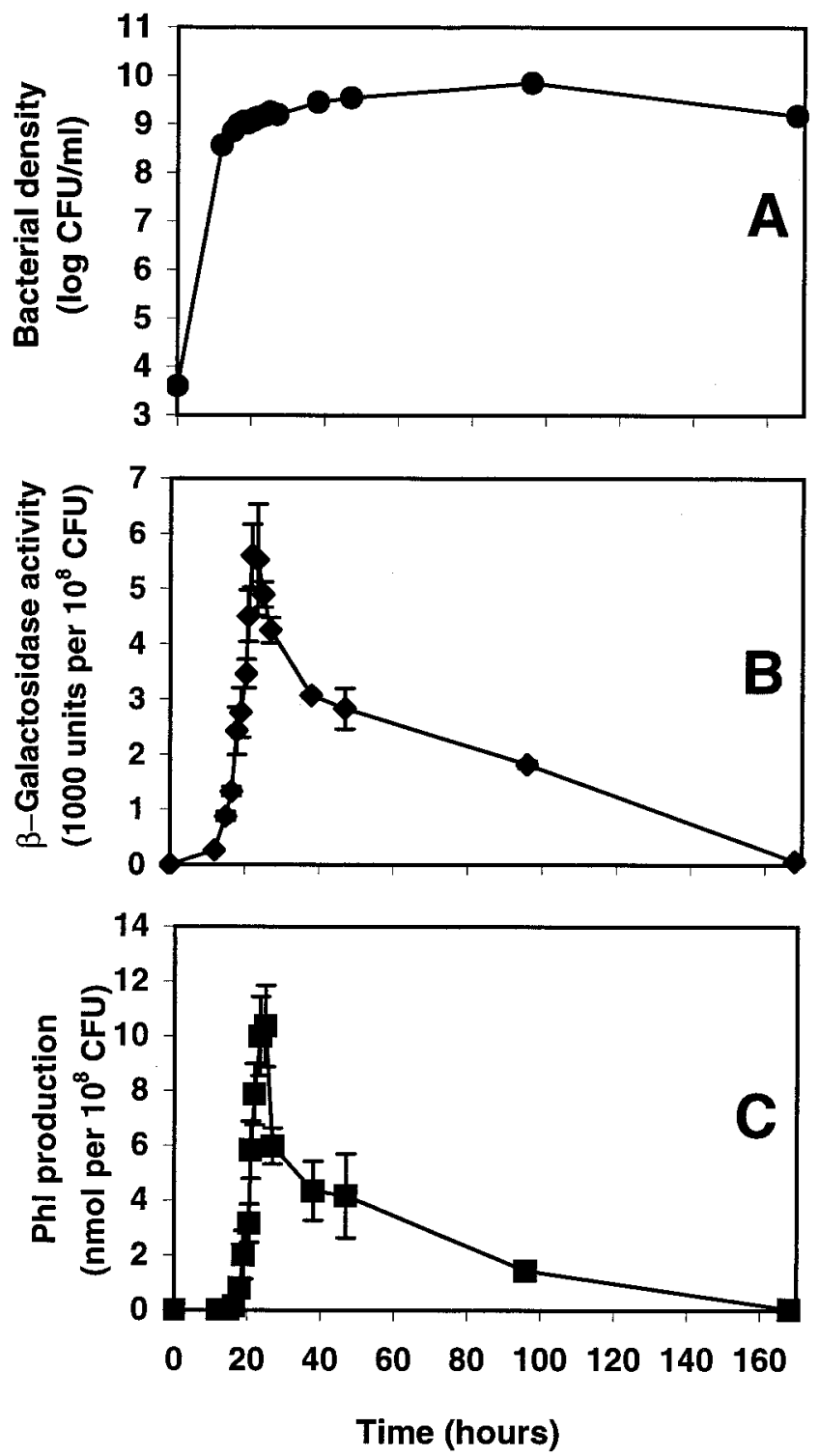

Fig. 1. Production of 2,4-diacetylphloroglucinol (DAPG) and expression of a translational phlA'-'lacZ fusion in Pseudomonas fluorescens CHA0. Strain CHA0/pME6259 was cultured in King's B medium broth at $27^{\circ} \mathrm{C}$. Samples were taken over a period of 7 days to A, determine bacterial density (log $\mathrm{CFU} / \mathrm{ml}), \mathbf{B}, \beta$-galactosidase activity, and $\mathbf{C}, \mathrm{DAPG}$ production. Means \pm standard deviation from four experiments are shown. Some of the error bars are too small to be distinguished. 
approximately 70 units per $10^{8} \mathrm{CFU}$ by the next sampling taken at 3 days after planting, and remained at that general level throughout 22 days of plant growth. This early peak in activity resulted solely from phlA gene expression in the rhizosphere, and cannot be attributed to the negligible background activity in the inoculum that was applied to pregerminated seedlings. When we sampled seedlings just $3 \mathrm{~h}$ after planting, $\beta$-galactosidase activity was essentially at background levels, below 10 units per $10^{8} \mathrm{CFU}$ (Fig. 3).

Influence of maize cultivar on phlA expression. Maize was used as a model to further examine the effect of host genotype at the cultivar level. We found significant differences in bacterial gene expression among six maize hybrids from Switzerland (Antares, Corso, and Magister) and the United States (Max 88, N4660, and
N4660 Bt) $(P=0.009)$ (Fig. 4). Whereas large variation was observed among the conventional cultivars, there was no difference in $p h l A^{\prime}-' l a c Z$ expression on transgenic N4660 Bt compared with the near-isogenic parent line N4660 (Fig. 4).

Influence of pathogen infection on phlA expression. Reporter gene expression in CHA0/pME6259 was monitored in the rhizospheres of plants grown in artificial soil that was infested with Pythium ultimum and in noninfested artificial soil. Pathogen infection significantly increased $\beta$-galactosidase activity in the rhizosphere of cucumber by three to sixfold compared with noninfected controls $(P \leq 0.047)$ (Table 1). Likewise, infection stimulated $\beta$-galactosidase activity in the rhizosphere of maize by two to fivefold $(P \leq 0.003)$ (Table 2$)$. Whereas the increase in gene
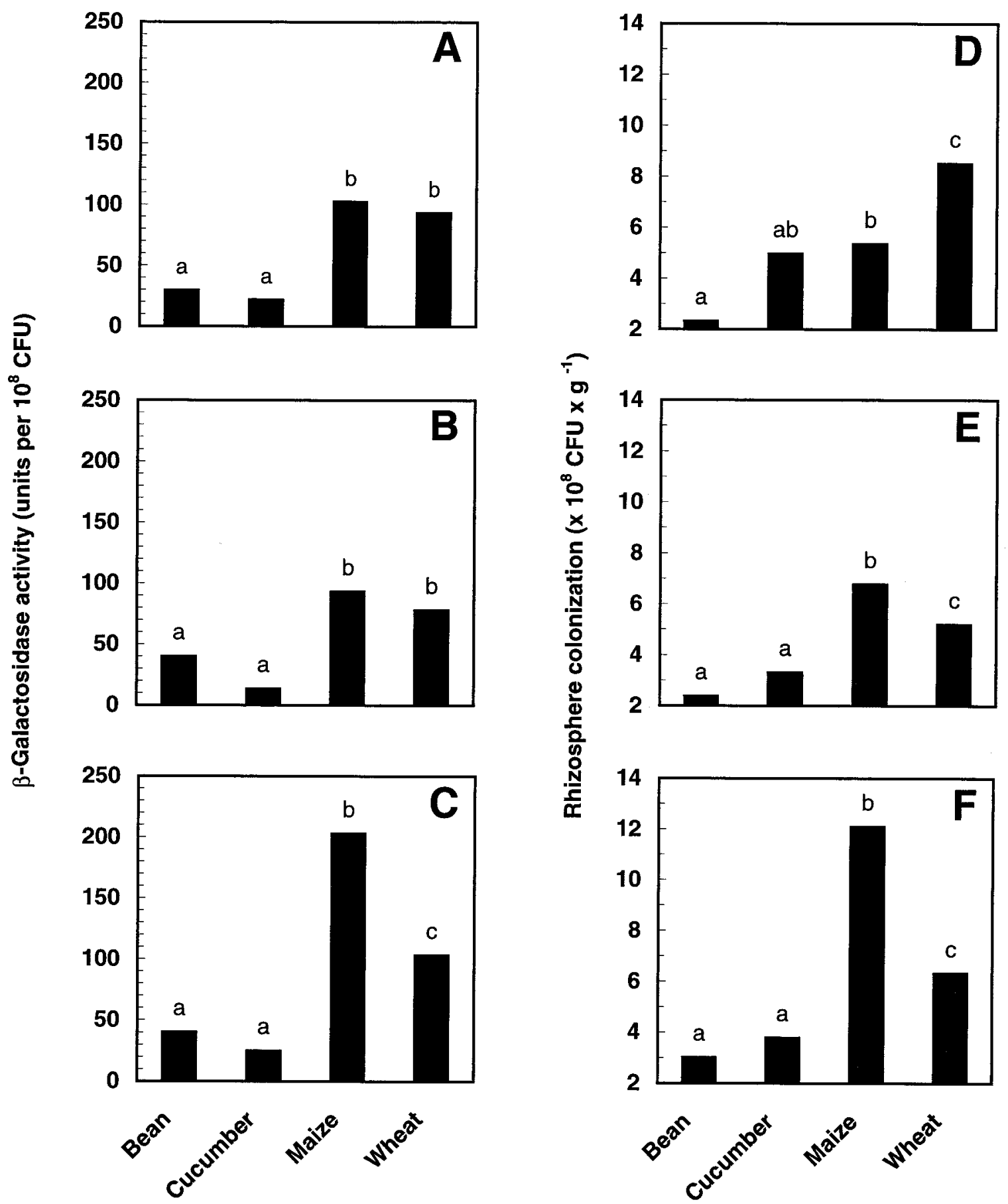

Fig. 2. Expression of a phlA'-'lacZ fusion in Pseudomonas fluorescens CHA0 harboring plasmid pME6259 in the rhizosphere of bean, cucumber, maize, and wheat. Plants were grown under gnotobiotic conditions in artificial soil, and roots were assessed for $\beta$-galactosidase activity and root colonization after $\mathbf{A}$ and D, 3 days, $\mathbf{B}$ and $\mathbf{E}, 5$ days, and $\mathbf{C}$ and $\mathbf{F}, 10$ days. Each bar is the mean of four independent experiments with four repetitions each. Bars with a common letter are not significantly different according to Fisher's protected least significant difference test at $P=0.05$. 
expression on cucumber was accompanied by a 7 - to 20 -fold increase in rhizosphere colonization $(P \leq 0.031)$ (Table 1$)$, no such relationship was observed on maize where bacterial colonization was the same in the presence or absence of Pythium ultimum $(P \geq 0.575)$ (Table 2).

Pathogen infection reduced growth of both maize and cucumber measured as reductions in root and plant fresh weights, and reduced seedling emergence. Clearly though, growth of cucumber (Table 1) was more severely affected than growth of maize (Table 2). Despite consistent increases in $p h l A^{\prime}$ - $^{\prime} l a c Z$ reporter gene expression in the rhizospheres of both cucumber and maize, the level of plant protection afforded by CHA0/pME6259 was inconsistent. Bacterial treatment slightly increased seedling emergence, but only in two of three trials for either cucumber (Table 1) or maize (Table 2 ). Root fresh weight was not increased significantly in any trial for cucumber or maize, and plant fresh weight was only increased in one of three trials for cucumber. In the absence of the pathogen, CHA0/pME6259 applied to roots caused a slight but significant reduction in root and plant fresh weight of cucumber in two of three trials (Table 1). There was no adverse effect on cucumber seedling emergence. Bacterial treatment had no such adverse effect on growth of maize in the absence of Pythium ultimum (Table 2). There were no differences in the effects reported here for $\mathrm{CHA} 0 /$ pME6259 and those observed with the wild-type parent strain CHA0 used as controls for background $\beta$-galactosidase activity measurement (data not shown).

Correlation of $p h l A^{\prime}-$ lacZ reporter gene expression with DAPG production in the rhizosphere. We monitored gene expression in parallel with direct extraction of the antimicrobial compound from the rhizospheres of one monocot and one dicot. $\beta$-Galactosidase activity of strain CHA0/pME6259 ranged between 185 and 229 units per $10^{8} \mathrm{CFU}$ in the maize rhizosphere and between 11 and 22 units per $10^{8} \mathrm{CFU}$ in the cucumber rhizosphere (Table 3 ). In the maize rhizosphere, DAPG produced by CHA0/pME6259 was detected at levels of 11.8 to $12.0 \mathrm{nmol} / \mathrm{g}$ of
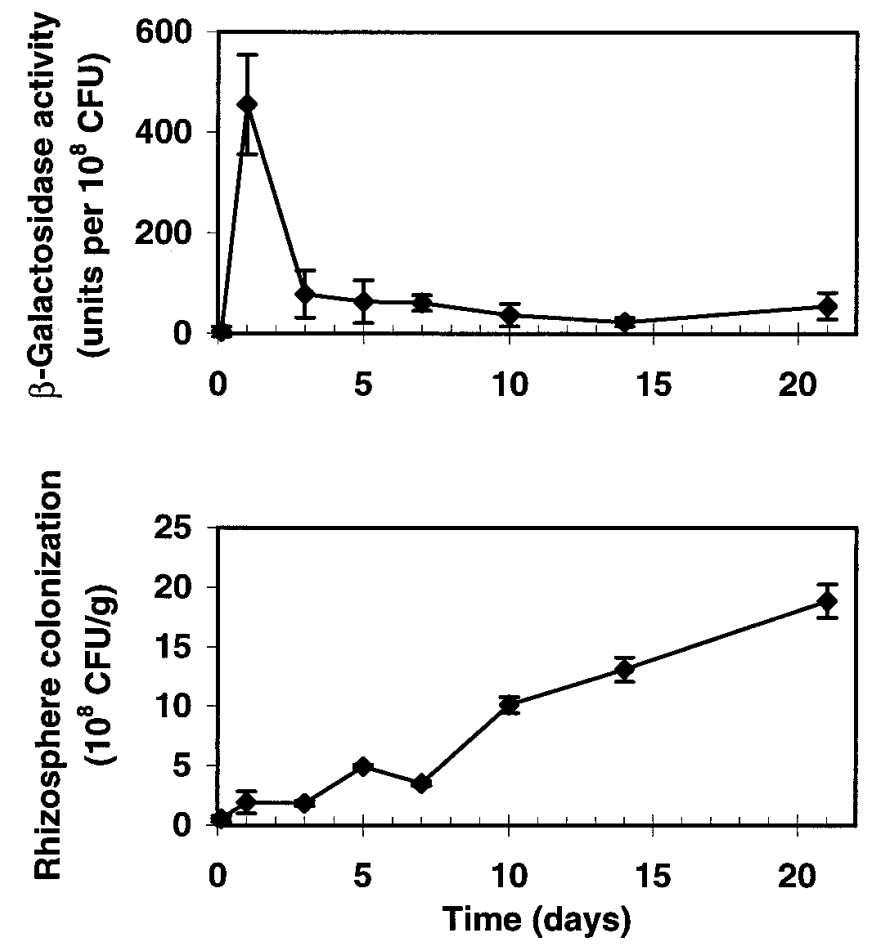

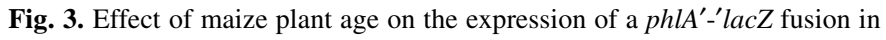
Pseudomonas fluorescens CHA0/pME6259. Plants were grown in artificial soil and under gnotobiotic conditions in Erlenmeyer flasks. Samples were taken at $3 \mathrm{~h}$ and $1,3,5,7,10,14$, and 21 days after planting. Values represent the mean of four flasks with \pm standard deviation of the mean. root. Adjusted for bacterial colonization, this was equivalent to 0.60 to $0.69 \mathrm{nmol}$ per $10^{8} \mathrm{CFU}$ (Table 3 ). In the cucumber rhizophere, no DAPG was detected. DAPG was also not detected in plants without bacteria added. Our detection limits for DAPG were $0.14 \mathrm{nmol} / \mathrm{g}$ root and $0.07 \mathrm{nmol}$ per $10^{8} \mathrm{CFU}$. Average plant fresh weights were approximately $1.2 \mathrm{~g}$ for maize and $0.72 \mathrm{~g}$ for cucumber. Bacterial inoculation had no effect on plant fresh weights in these experiments, where pathogens were not added (Table 3).

Bacterial rhizosphere colonization. Throughout our study, rhizosphere population densities of Pseudomonas fluorescens CHA0/pME6259 were generally higher on monocots than on dicots. For example, in the experiment with parallel monitoring of gene expression and DAPG production, colonization was over $1 \mathrm{log}$ CFU greater on maize than on cucumber after 7 days growth (Table 3). There was a significant interaction, though, between plant species and plant age as seen in our initial gnotobiotic experiment $(P \leq 0.0001)$ (Fig. 2). After 3 days, colonization of maize was greater than that of bean but the same as that of cucumber, and only wheat was colonized significantly better than were both dicots $(P \leq 0.0001)$ (Fig. 2A). By 5 and 10 days, however, colonization of either monocot was significantly greater than colonization of cucumber or bean $(P \leq 0.0001)$ (Fig. 2B and C).

\section{DISCUSSION}

Our reporter gene system, phlA'-'lacZ, was a sensitive tool to monitor Pseudomonas fluorescens phl gene expression in the rhizosphere. By comparing $\beta$-galactosidase activity with DAPG extracted from the rhizosphere of maize, we were able to show, for the first time, that gene expression reflected DAPG biosynthesis in the rhizosphere. This is also the first direct evidence for
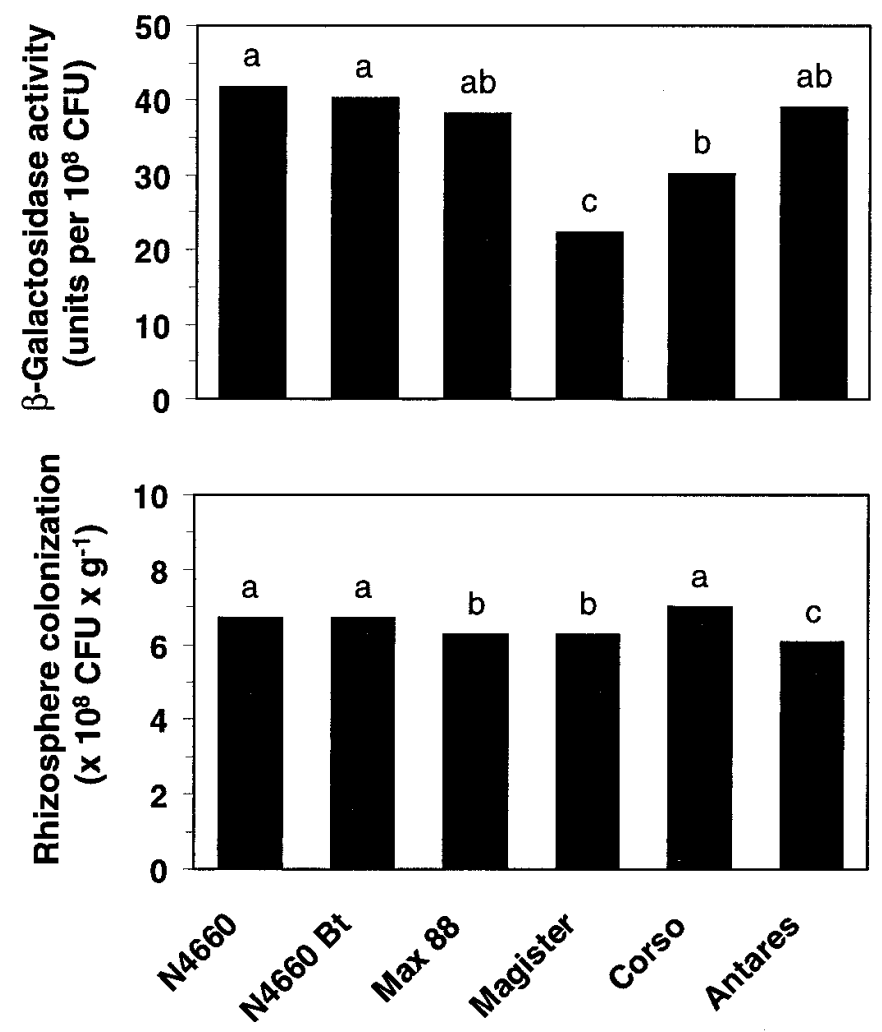

Fig. 4. Effect of maize cultivar on bacterial gene expression and rhizosphere colonization. Plants were grown under gnotobiotic conditions in artificial soil and roots were assessed for $\beta$-galactosidase activity and root colonization after 6 days. Each bar represents the mean of eight replicate flasks with five seedlings each. Bars with a common letter are not significantly different according to Fisher's protected least significant difference test at $P=0.05$. 
production of an antimicrobial metabolite by a biocontrol strain in the maize rhizosphere. DAPG, phenazine-1-carboxylic acid, and pyoluteorin have previously been isolated from wheat $(4,21,29$, $39,49)$. In the cucumber rhizosphere, our reporter gene was able to predict DAPG production at levels below that which could be measured by DAPG extraction. Direct isolation procedures are technically difficult and laborious. As an alternative, various reporter genes, including lux, inaZ, and lacZ, have been used to monitor production of phenazine, pyoluteorin, and oomycin A production by Pseudomonas spp. in the rhizospheres of cotton, cucumber, sugar beat, tomato, and wheat $(6,16,20,25,51)$. One concern with any reporter gene is that the product should not be overly stable, otherwise activity levels will reflect cumulative rather than current expression of the target gene (27). The fact that $\beta$-galactosidase levels dramatically rose and gradually fell from day to day in our time course experiment with maize, indicates that the $p h l A^{\prime}-{ }^{\prime} l a c Z$ reporter gene used in this study reflected temporal gene expression. Previous in vitro experiments comparing gene expression and production of DAPG have suggested that the bacterium itself gradually degrades $\beta$-galactosidase, but that the enzyme is more stable than DAPG, which is degraded by strain CHA0 to monoacetylphloroglucinol (43).

Host genotype at the species level had a dramatic effect on phlA gene expression, with the greatest differences observed between monocot and dicot species. DAPG gene expression was consistently two to fourfold higher in the rhizospheres of maize and wheat than with bean and cucumber in our experiments. Georgakopoulos et al. (16) also found slightly higher expression of phenazine biosynthetic genes on wheat than on the dicots, cotton and sugar beet. Interestingly, greater levels of antibiotic production did not appear to translate into more effective protection of monocots versus dicots, as may have been expected. Although different host sus- ceptibilities to disease may partly explain this, poor distribution of the enhanced antimicrobial metabolite quantities in the infection court may be involved. It is also possible that a threshold level was obtained, and that no further benefit was achieved with additional DAPG. Rather the benefits may have been out-weighed by phytotoxic effects of the extra DAPG. This hypothesis is supported by Maurhofer et al. $(29,30)$ who found that an antimicrobial compound over-producing transgenic derivative of strain CHA0 was phytotoxic to maize and did not offer enhanced biological control of Pythium root rot compared with the wild type. In contrast, the DAPG over-producer was not phytotoxic to cucumber, and it provided superior disease protection. Phytotoxity from DAPG or pyoluteorin, which is also produced by CHA0, thus does not offer an explanation for the slight growth inhibition of cucumber we observed after inoculation with our reporter strain in the absence of Pythium (Table 1). Strain CHA0 produces an extraordinary array of antimicrobial secondary metabolites, several of which may exhibit phytotoxicity, including hydrogen cyanide (8). Any problems with plasmid pME6259 carrying our reporter gene can be ruled out, because the same effects on cucumber growth were observed with wild-type CHA0 not carrying the plasmid. Inconsistent protection of cucumber and maize (Tables 1 and 2) by strain CHA0/pME6259 might be due to the special method of inoculum preparation used to minimize phl gene expression at the beginning of each plant experiment.

Host genotype at the cultivar level also had an influence on gene expression. To our knowledge, this is the first study to show that production of an antimicrobial compound varies among cultivars of the same species, and it might offer one plausible explanation for variation in biocontrol activity that has previously been reported between cultivars (46). Using maize as a model, we

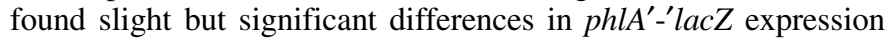

TABLE 1. Expression of a phlA'-lacZ fusion in Pseudomonas fluorescens CHA0/pME6259 in the cucumber rhizosphere during damping-off caused by Pythium ultimum ${ }^{\mathrm{w}}$

\begin{tabular}{|c|c|c|c|c|c|c|c|c|c|c|c|c|}
\hline \multirow[b]{2}{*}{ Pseudomonas fluorescens CHA0/pME6259 } & \multicolumn{4}{|c|}{ Experiment 1} & \multicolumn{4}{|c|}{ Experiment 2} & \multicolumn{4}{|c|}{ Experiment 3} \\
\hline & - & + & - & + & - & + & - & + & - & + & - & + \\
\hline Pythium ultimum & - & - & + & + & - & - & + & + & - & - & + & + \\
\hline $\begin{array}{l}\text { Root fresh weight }(\mathrm{mg})^{x} \\
\text {. }\end{array}$ & $134 \mathrm{a}$ & $99 \mathrm{~b}$ & $14 \mathrm{c}$ & $19 \mathrm{c}$ & $123 \mathrm{a}$ & $89 \mathrm{~b}$ & $28 \mathrm{c}$ & $41 \mathrm{c}$ & $140 \mathrm{a}$ & $125 \mathrm{a}$ & $15 \mathrm{~b}$ & $26 \mathrm{~b}$ \\
\hline Plant fresh weight $(\mathrm{mg})^{\mathrm{x}}$ & $519 \mathrm{a}$ & $420 \mathrm{~b}$ & $77 \mathrm{c}$ & $113 \mathrm{c}$ & $487 \mathrm{a}$ & $367 \mathrm{~b}$ & $107 \mathrm{c}$ & $152 \mathrm{c}$ & $511 \mathrm{a}$ & $469 \mathrm{a}$ & $59 \mathrm{~b}$ & $132 \mathrm{c}$ \\
\hline Emergence of seedlings $(\%)^{\mathrm{y}}$ & $100 \mathrm{a}$ & $100 \mathrm{a}$ & $70 \mathrm{~b}$ & $80 \mathrm{~b}$ & $100 \mathrm{a}$ & $100 \mathrm{a}$ & $65 \mathrm{~b}$ & $85 \mathrm{a}$ & $100 \mathrm{a}$ & $100 \mathrm{a}$ & $90 \mathrm{~b}$ & $100 \mathrm{a}$ \\
\hline$\beta$-Galactosidase activity (units per $\left.10^{8} \mathrm{CFU}\right)^{\mathrm{z}}$ & nd & $10.8 \mathrm{a}$ & nd & $38.0 \mathrm{~b}$ & nd & $9.4 \mathrm{a}$ & nd & $51.1 \mathrm{~b}$ & nd & $2.7 \mathrm{a}$ & nd & $10.1 \mathrm{~b}$ \\
\hline Rhizosphere colonization $\left(\times 10^{8} \mathrm{CFU} \times \mathrm{g}^{-1}\right)$ & nd & $6.4 \mathrm{a}$ & nd & $131.7 \mathrm{~b}$ & nd & $7.16 \mathrm{a}$ & nd & $52.8 \mathrm{~b}$ & nd & $4.5 \mathrm{a}$ & nd & $87.0 \mathrm{~b}$ \\
\hline
\end{tabular}

${ }^{\mathrm{w}}$ Strain CHA0/pME6259, a derivative of wild-type Pseudomonas fluorescens CHA0 carrying a phlA'-'lacZ translational fusion on plasmid pME6259 (43).

Means for the same experiment within the same row followed by a different letter are significantly different at $P \leq 0.05$ according to Fisher's least significant difference test. nd indicates that neither $\beta$-galactosidase activity nor Pseudomonas fluorescens CHA0/pME6259 were detected.

${ }^{x}$ Plants were grown for 7 days under gnotobiotic conditions in artificial soil with or without the addition of Pythium ultimum. Fresh weight per plant.

y Percentage of emerged seedlings $(100 \%=$ five plants).

${ }^{z} \beta$-Galactosidase activity is indicated per $10^{8} \mathrm{CFU}$.

TABLE 2. Expression of a phlA'-'lacZ fusion in Pseudomonas fluorescens CHA0/pME6259 in the maize rhizosphere during damping-off caused by Pythium ultimum $^{\mathrm{w}}$

\begin{tabular}{|c|c|c|c|c|c|c|c|c|c|c|c|c|}
\hline \multirow[b]{2}{*}{ Pseudomonas fluorescens CHA0/pME6259 } & \multicolumn{4}{|c|}{ Experiment 1} & \multicolumn{4}{|c|}{ Experiment 2} & \multicolumn{4}{|c|}{ Experiment 3} \\
\hline & - & + & - & + & - & + & - & + & - & + & - & + \\
\hline Pythium ultimum & - & - & + & + & - & - & + & + & - & - & + & + \\
\hline Plant fresh weight $(\mathrm{mg})^{\mathrm{x}}$ & $735 \mathrm{a}$ & $690 \mathrm{a}$ & $408 \mathrm{~b}$ & $452 \mathrm{~b}$ & $531 \mathrm{a}$ & $511 \mathrm{a}$ & $240 \mathrm{~b}$ & $347 \mathrm{ab}$ & $718 \mathrm{a}$ & $674 \mathrm{a}$ & $344 \mathrm{~b}$ & $354 \mathrm{~b}$ \\
\hline Emergence of seedlings $(\%)^{\mathrm{y}}$ & $100 \mathrm{a}$ & $100 \mathrm{a}$ & $100 \mathrm{a}$ & $100 \mathrm{a}$ & $100 \mathrm{a}$ & $100 \mathrm{a}$ & $80 \mathrm{~b}$ & $100 \mathrm{a}$ & $100 \mathrm{a}$ & $100 \mathrm{a}$ & $90 \mathrm{~b}$ & $100 \mathrm{a}$ \\
\hline$\beta$-Galactosidase activity (units per $\left.10^{8} \mathrm{CFU}\right)^{\mathrm{z}}$ & nd & $24 \mathrm{a}$ & nd & $119 \mathrm{~b}$ & nd & $45 \mathrm{a}$ & nd & $106 \mathrm{~b}$ & nd & $14 \mathrm{a}$ & nd & $41 \mathrm{~b}$ \\
\hline Rhizosphere colonization $\left(\times 10^{8} \mathrm{CFU} \times \mathrm{g}^{-1}\right)$ & nd & $6.81 \mathrm{a}$ & nd & $7.56 \mathrm{a}$ & nd & $8.59 \mathrm{a}$ & nd & $8.95 \mathrm{a}$ & nd & $9.43 \mathrm{a}$ & nd & $9.86 \mathrm{a}$ \\
\hline
\end{tabular}

${ }^{w}$ Strain CHA0/pME6259, a derivative of wild-type Pseudomonas fluorescens CHA0 carrying a phlA'-'lacZ translational fusion on plasmid pME6259 (43).

Means for the same experiment within the same row followed by a different letter are significantly different at $P \leq 0.05$ according to Fisher's least significant difference test. nd indicates that neither $\beta$-galactosidase activity nor Pseudomonas fluorescens CHA0/pME6259 were detected.

${ }^{x}$ Plants were grown for 7 days under gnotobiotic conditions in artificial soil with or without the addition of Pythium ultimum. Fresh weight per plant.

y Percentage of emerged seedlings $(100 \%=$ five plants $)$.

${ }^{\mathrm{z}} \beta$-Galactosidase activity is indicated per $10^{8} \mathrm{CFU}$. 
on six U.S. and Swiss maize cultivars. Our work further emphasizes the importance of considering interactions with biocontrol agents in crop breeding programs, and offers a screening approach for selecting varieties that support optimal antimicrobial metabolite production by bacteria. It is also noteworthy, that while there were differences among cultivars from traditional breeding programs (e.g., 'Magister' versus 'Antares'), no such difference was observed between wild-type N4660 and the near-isogenic transgenic line N4660 Bt carrying the $c r y l A b$ insecticidal gene from $B$. thuringiensis. A recent note reporting release of $c r y 1 A b$ by $\mathrm{N} 4660$ into the rhizosphere (42) raised considerable concern about unforeseen nontarget impact. To our knowledge, this is the first study to address microbial interactions with transgenic Bt maize in the rhizosphere, and we found no evidence for any impact, negative or positive.

The most obvious explanation for differences in DAPG production between plant species and crop cultivars is differences in the quantity and or quality of root exudates. Production of antimicrobial compounds by biocontrol bacteria is modulated by the total concentration and the type of carbon source, nitrogen, amino acids, and other compounds found abundantly in plant root exudates but lacking in bulk soil $(10,14,33,34,44)$. Rhizosphere $\mathrm{pH}$, which can be modified by root exudates, also affects bacterial antimicrobial metabolite production and possibly stability once produced $(36,45,52)$. The composition of root exudates can be very species specific $(7,17,37)$. Maize root exudates were reported to enhance IAA production in Pseudomonas fluorescens M.3.1. in vitro (2). Evidence for a distinct response of gene expression in Pseudomonas fluorescens R2f to exudates of mono- and dicotyledonous plants has been provided by van Overbeek and van Elsas (50) who screened Tn5-B20 (lacZ transcriptional fusion) mutants of strain R2f for their response to root exudates, and found that reporter gene expression was enhanced in the presence of wheat, maize, and grass roots but not in the presence of clover roots. Milner et al. (33) reported that alfalfa sprout exudates stimulated zwittermicin A production by B. cereus UW85. In the end though, obtaining exudates from plants growing under natural conditions for testing in vitro remains problematic.

Plant age had an influence on DAPG gene expression, but this was host-species dependent. We observed very little difference for bean, cucumber, or wheat at 3,5, and 10 days after planting, whereas expression on maize was approximately doubled between 5 and 10 days, from 93 to $202 \beta$-galactosidase units per $10^{8} \mathrm{CFU}$ in one experiment. However, this was a relatively small change compared with that observed in a follow-up experiment that more closely examined the effect of maize age. In this experiment, DAPG gene expression rapidly increased from nondetectable at planting to peak at $455 \beta$-galactosidase units per $10^{8} \mathrm{CFU}$ at 1 day after planting. Levels dropped by 3 days after planting to approximately $50 \beta$-galactosidase units per $10^{8} \mathrm{CFU}$, which was stable for 20 days of plant growth. This indicates that relatively large quantities of DAPG can be produced early on during the interaction, which may be essential for controlling Pythium root rot and other disease that have a rapid onset (28). It also indicates that stable levels of antibiotic metabolite production sufficient for pathogen inhibition (21) can be sustained throughout plant growth, which may offer longer term disease protection. There is evidence that the effect of plant age may be linked to changes in root exudate quality and quantity $(18,47)$. Richardson et al. (40) found that nod gene induction in Rhizobium trifolii changed with host plant age.

Differential root colonization is another factor that may contribute to host genotype variation in gene expression. There is convincing evidence that different species and cultivars can greatly vary in their ability to support bacterial rhizosphere populations (46). It is also known that antimicrobial metabolite biosynthesis can be cell-density dependent, with a certain threshold of cells needed before biosynthetic genes are up-regulated. This has been attributed to quorum sensing mediated by autoinducing molecules produced by the bacteria. Autoinducing homoserine lactones positively regulate phenazine production by Pseudomonas aureofaciens in the wheat rhizosphere (38). In strain CHA0, secondary metabolism is regulated by the GacS/GacA two-component system in a cell-density-dependent manner (3), and DAPG has been identified as a positive autoinducer for the phl biosynthetic locus (43). However, root colonization alone does not explain the differences we observed for DAPG gene expression. For example, wheat root populations decreased from 3 to 10 days after planting but there was no change in gene expression during that time. In maize, there was a peak in gene expression early on during growth, when rhizosphere populations were just increasing. Furthermore, populations were lowest on 'Antares', which was among the highest for gene expression levels among maize cultivars. This indicates that the host plant had at least some direct effect on bacterial gene expression, rather than only an indirect effect via increased bacterial numbers.

Root infection with Pythium ultimum stimulated phlA'-'lacZ gene expression on both cucumber and maize by two to sixfold. Bull et al. (5) reported a positive linear relationship between wheat root disease and bacterial root colonization. Mazzola and Cook (31) found that the relationship was specific depending on bacterial strain and Pythium spp. However, in our study, changes in $p h l$ gene expression were not always correlated with bacterial population sizes. For example, although populations were increased on infected cucumber they were not significantly different on healthy or infected maize. It may be that the sudden release of plant compounds from a thoroughly devastated root system of cucumber was more beneficial to the bacterium than the slower release of compounds from maize, which suffered less obvious root damage. Our study is the first to demonstrate that pathogen

TABLE 3. Parallel $\beta$-galactosidase assay and production of 2,4-diacetylphloroglucinol (DAPG) in the rhizosphere of maize and cucumber ${ }^{u}$

\begin{tabular}{|c|c|c|c|c|c|c|c|c|c|c|c|}
\hline \multirow{3}{*}{$\begin{array}{l}\text { Plant } \\
\text { species }^{v}\end{array}$} & \multirow{3}{*}{$\begin{array}{l}\text { Pseudomonas } \\
\text { fluorescens }^{\mathrm{w}}\end{array}$} & \multirow{2}{*}{\multicolumn{2}{|c|}{$\begin{array}{c}\beta \text {-Galactosidase } \\
\text { activity (units per } \\
\left.10^{8} \mathrm{CFU}\right)^{\mathrm{x}}\end{array}$}} & \multicolumn{4}{|c|}{ nmol of DAPG per ${ }^{y}$} & \multirow{2}{*}{\multicolumn{2}{|c|}{ Plant fresh weight $(\mathrm{mg})^{\mathrm{z}}$}} & \multirow{2}{*}{\multicolumn{2}{|c|}{$\begin{array}{l}\text { Root colonization } \\
\left(\times 10^{8} \mathrm{CFU} \mathrm{g} \mathrm{g}^{-1}\right)\end{array}$}} \\
\hline & & & & \multicolumn{2}{|c|}{$10^{8} \mathrm{CFU}$} & \multicolumn{2}{|c|}{$\mathrm{g}$ of root } & & & & \\
\hline & & Expt. 1 & Expt. 2 & Expt. 1 & Expt. 2 & Expt. 1 & Expt. 2 & Expt. 1 & Expt. 2 & Expt. 1 & Expt. 2 \\
\hline Maize & None & nd & nd & nd & nd & nd & nd & $1,198 \mathrm{a}$ & $1,215 \mathrm{a}$ & nd & nd \\
\hline Maize & CHA0/pME6259 & $229 a$ & $185 \mathrm{a}$ & 0.691 & 0.596 & 11.97 & 11.78 & $1,279 \mathrm{a}$ & $1,218 \mathrm{a}$ & $13.56 \mathrm{a}$ & $14.52 \mathrm{a}$ \\
\hline Cucumber & None & nd & nd & nd & nd & nd & nd & $716 \mathrm{~b}$ & $729 \mathrm{~b}$ & nd & nd \\
\hline Cucumber & CHA0/pME6259 & $22 \mathrm{~b}$ & $11 \mathrm{~b}$ & $<0.07$ & $<0.07$ & $<0.14$ & $<0.14$ & $757 \mathrm{~b}$ & $743 \mathrm{~b}$ & $2.77 \mathrm{~b}$ & $2.97 \mathrm{~b}$ \\
\hline
\end{tabular}

${ }^{\mathrm{u}}$ Means within columns followed by a different letter are significantly different at $P \leq 0.05$ according to Fisher's least significant difference test. nd indicates that neither $\beta$-galactosidase activity nor DAPG nor Pseudomonas fluorescens CHA0/pME6259 were detected.

${ }^{v}$ Plants were grown for 10 days under gnotobiotic conditions in artificial soil.

w Strain CHA0/pME6259, a derivative of wild-type Pseudomonas fluorescens CHA0 carrying a phlA'-'lacZ translational fusion on plasmid pME6259 (43).

$\times \beta$-Galactosidase activity is indicated per $10^{8} \mathrm{CFU}$. Experiments 1 and 2 are two independent experiments.

y DAPG was extracted from the roots and the adhering artificial soil from 130 (maize) or 210 (cucumber) plants per treatment.

${ }^{\mathrm{z}}$ Fresh weight per plant. 
attack increases expression of a critical biocontrol gene in a wildtype strain. These results support our previous observations that the production of DAPG by transgenic antimicrobial metabolite over-producing strain CHA0/pME3090 was enhanced in the rhizosphere of wheat infected with Pythium ultimum compared with healthy plants (29). Fedi et al. (13) reported that contents leaked from Pythium ultimum mycelia repressed expression of 9 out of 5,000 promoterless genes randomly tagged with a lacZ reporter gene Pseudomonas fluorescens F113. None of the affected genes were directly involved in biological control, including genes for DAPG production, but some of the genes may have been involved in root colonization. Gaballa et al. (15) found evidence that trehalose was a Pythium-derived signal responsible for stimulating trehalase genes in another root-colonizing Pseudomonas fluorescens strain, and that these genes contribute to root colonization. This offers an explanation for the link between bacterial root colonization and Pythium. It also suggests that in our study, increased DAPG gene expression can probably be attributed to an indirect effect of disease (e.g., increased release of root exudates) rather than to a direct signaling from the pathogen, which has so far only been seen in the Fusarium-Pseudomonas-tomato system (9).

\section{ACKNOWLEDGMENTS}

This study was supported by the Swiss National Foundation for Scientific Research (Project 31-50522.97) and the Swiss Federal Office for Environment (OFEFP Project 310.97.66). We thank C. Saez and M. Lutz for assistance with maize cultivar bioassays.

\section{LITERATURE CITED}

1. Bangera, M. G., and Thomashow, L. S. 1999. Identification and characterization of a gene cluster for synthesis of the polyketide antibiotic 2,4-diacetylphloroglucinol from Pseudomonas fluorescens Q287. J. Bacteriol. 181:3155-3163.

2. Benizri, E., Courtade, A., Picard, C., and Guckert, A. 1998. Role of maize root exudates in the production of auxins by Pseudomonas fluorescens M.3.1. Soil Biol. Biochem. 30:1481-1484.

3. Blumer, C., Heeb, S., Pessi, G., and Haas, D. 1999. Global GacA-steered control of cyanide and exoprotease production in Pseudomonas fluorescens involves specific ribosome binding sites. Proc. Natl. Acad. Sci. USA 96:14073-14078.

4. Bonsall, R. F., Weller, D. M., and Thomashow, L. S. 1997. Quantification of 2,4-diacetylphloroglucinol produced by fluorescent Pseudomonas spp. in vitro and in the rhizosphere of wheat. Appl. Environ. Microbiol. 63:951-955.

5. Bull, C. T., Weller, D. M., and Thomashow, L. S. 1991. Relationship between root colonization and suppression of Gaeumannomyces graminis var. tritici by Pseudomonas fluorescens strain 2-79. Phytopathology 81:954-959.

6. Chin-A-Woeng, T. F. C., Bloemberg, G. V., van der Bij, A. J., van der Drift, K. M. G. M., Schripsema, J., Kroon, B., Scheffer, R. J., Keel, C., Bakker, P. A. H. M., Tichy, H. V., de Bruijn, F. J., Thomas-Oates, J. E., and Lugtenberg, B. J. 1998. Biocontrol by phenazine-1-carboxamideproducing Pseudomonas chlororaphis PCL1391 of tomato root rot caused by Fusarium oxysporum f. sp. radicis-lycopersici. Mol. PlantMicrobe Interact. 11:1069-1077.

7. Cieslinski, G., Van-Rees, K. C. J., Szmigielska, A. M., and Huang, P. M. 1997. Low molecular weight organic acids released from roots of durum wheat and flax into sterile nutrient solutions. J. Plant Nutr. 20:753-764.

8. Défago, G., and Keel, C. 1995. Pseudomonads as biocontrol agents of diseases caused by soil-borne pathogens. Pages 137-148 in: Benefits and Risks of Introducing Biocontrol Agents. H. M. T. Hokkanen and J. M. Lynch, eds. Cambridge University Press, England.

9. Duffy, B. K., and Défago, G. 1997. Zinc improves biocontrol of Fusarium crown and root rot of tomato by Pseudomonas fluorescens and represses the production of pathogen metabolites inhibitory to bacterial antibiotic biosynthesis. Phytopathology 87:1250-1257.

10. Duffy, B. K., and Défago, G. 1999. Environmental factors modulating antibiotic and siderophore biosynthesis by Pseudomonas fluorescens biocontrol strains. Appl. Environ. Microbiol. 65:2429-2438.

11. Duffy, B. K., Ownley, B. H., and Weller, D. M. 1997. Soil chemical and physical properties associated with suppression of take-all of wheat by Trichoderma koningii. Phytopathology 87:1118-1124.

12. Engelhard, A. W. 1989. Soilborne Plant Pathogens: Management of
Diseases with Macro- and Microelements. The American Phytopathological Society, St. Paul, MN.

13. Fedi, S., Tola, E., Moënne-Loccoz, Y., Dowling, D. N., Smith, L. M., and O'Gara, F. 1997. Evidence for signaling between the phytopathogenic fungus Pythium ultimum and Pseudomonas fluorescens F113: P. ultimum represses the expression of genes in $P$. fluorescens $\mathrm{F} 113$, resulting in altered ecological fitness. Appl. Environ. Microbiol. 63:4261-4266.

14. Fiddaman, P. J., and Rossall, S. 1994. Effect of substrate on the production of antifungal volatiles from Bacillus subtilis. J. Appl. Bacteriol. 76:395-405.

15. Gaballa, A., Abeysinghe, P. D., Urich, G., Matthijs, S., De Greve, H., Cornelis, P., and Koedam, N. 1997. Trehalose induces antagonism towards Pythium debaryanum in Pseudomonas fluorescens ATCC 17400. Appl. Environ. Microbiol. 63:4340-4345.

16. Georgakopoulos, D. G., Hendson, M., Panopoulos, N. J., and Schroth, M. N. 1994. Analysis of expression of a phenazine biosynthesis locus of Pseudomonas aureofaciens PGS12 on seeds with a mutant carrying a phenazine biosynthesis locus-ice nucleation reporter gene fusion. Appl. Environ. Microbiol. 60:4573-4579.

17. Guckert, A., Chavanon, M., Mench, M., Morel, J. L., and Villemin, G. 1991. Root exudation in Beta vulgaris: A comparison with Zea mays. Dev. Agric. Man. For. Ecol. 24:449-455.

18. Haller, T., and Stolp, H. 1985. Quantitative estimation of root exudation of maize plants. Plant Soil 86:207-216.

19. Heeb, S., Itoh, Y., Nishijyo, T., Schnider, U., Keel, C., Wade, J., Walsh, U., O'Gara, F., and Haas, D. 2000. Small stable shuttle vectors based on the minimal pVS1 replicon for use in gram-negative, plant-associated bacteria. Mol. Plant-Microbe Interact. 13:232-237.

20. Howie, W. J., and Suslow, T. V. 1991. Role of antibiotic biosynthesis in the inhibition of Pythium ultimum in the cotton spermosphere and rhizosphere by Pseudomonas fluorescens. Mol. Plant-Microbe Interact. 4:393-399.

21. Keel, C., Schnider, U., Maurhofer, M., Voisard, C., Laville, J., Burger, U., Wirthner, P., Haas, D., and Défago, G. 1992. Suppression of root diseases by Pseudomonas fluorescens CHA0: Importance of the bacterial secondary metabolite 2,4-diacetylphloroglucinol. Mol. Plant-Microbe Interact. 5:4-13.

22. Keel, C., Voisard, C., Berling, C. H., Kahr, G., and Défago, G. 1989. Iron sufficiency, a prerequisite for the suppression of tobacco black root rot by Pseudomonas fluorescens strain CHA0 under gnotobiotic conditions. Phytopathology 79:584-589.

23. King, E. O., Ward, M. K., and Raney, D. E. 1954. Two simple media for the demonstration of pyocyanin and fluorescin. J. Lab. Clin. Med. 44: 301-307.

24. Kraus, J., and Loper, J. E. 1992. Lack of evidence for a role of antifungal metabolite production by Pseudomonas fluorescens Pf-5 in biological control of Pythium damping-off of cucumber. Phytopathology 82:264271.

25. Kraus, J., and Loper, J. E. 1995. Characterization of a genomic region required for production of the antibiotic pyoluteorin by the biological control agent Pseudomonas fluorescens Pf-5. Appl. Environ. Microbiol. 61:849-854.

26. Lemanceau, P., and Alabouvette, C. 1993. Suppression of Fusarium wilts by fluorescent pseudomonads: Mechanisms and applications. Biocontrol Sci. Technol. 3:219-234.

27. Loper, J. E., and Lindow, S. E. 1997. Reporter gene systems useful in evaluating in situ gene expression by soil- and plant-associated bacteria. Pages 482-492 in: Manual of Environmental Microbiology. C. J. Hurst, G. R. Knudsen, M. J. McInervey, L. D. Stetzenbach, and M. V. Walter, eds. ASM Press, Washington, D.C.

28. Martin, F. N., and Loper, J. E. 1999. Soilborne plant diseases caused by Pythium spp.: Ecology, epidemiology, and prospects for biological control. Crit. Rev. Plant Sci. 18:111-181.

29. Maurhofer, M., Keel, C., Haas, D., and Défago, G. 1995. Influence of plant species on disease suppression by Pseudomonas fluorescens strain CHA0 with enhanced antibiotic production. Plant Pathol. 44:40-50.

30. Maurhofer, M., Keel, C., Schnider, U., Voisard, C., Haas, D., and Défago, G. 1992. Influence of enhanced antibiotic production in Pseudomonas fluorescens strain CHA0 on its disease suppressive capacity. Phytopathology 82:190-195.

31. Mazzola, M., and Cook, R. J. 1991. Effects of fungal root pathogens on the population dynamics of biocontrol strains of fluorescent pseudomonads in the wheat rhizosphere. Appl. Environ. Microbiol. 57:21712178.

32. Miller, J. H. 1992. A Short Course in Bacterial Genetics: A Laboratory Manual and Handbook for Escherichia coli and Related Bacteria. Cold Spring Harbor Laboratory, Cold Spring Harbor, New York.

33. Milner, J. L., Raffel, S. J., Lethbridge, B. J., and Handelsman, J. 1995. Culture conditions that influence accumulation of zwittermicin A by Bacillus cereus UW85. Appl. Microbiol. Biotechnol. 43:685-691. 
34. Milner, J. L., Silo-Suh, L., Lee, J. C., He, H., Clardy, J., and Handelsman, J. 1996. Production of kanosamine by Bacillus cereus UW85. Appl. Environ. Microbiol. 62:3061-3065.

35. Ownley, B. H., Weller, D. M., and Alldredge, J. R. 1991. Relation of soil chemical and physical factors with suppression of take-all by Pseudomonas fluorescens 2-79. IOBC/WPRS Bull. 14:299-301.

36. Ownley, B. H., Weller, D. M., and Thomashow, L. S. 1992. Influence of in situ and in vitro $\mathrm{pH}$ on suppression of Gaeumannomyces graminis var. tritici by Pseudomonas fluorescens 2-79. Phytopathology 82:178-184.

37. Pérez, F. J., and Ormeño-Nuñez, J. 1991. Difference in hydroxamic acid content in roots and root exudates of wheat (Triticum aestivum L.) and rye (Secale cereale L.): Possible role in allelopathy. J. Chem. Ecol. 17: 1037-1043.

38. Pierson, L. S., III, Wood, D. W., Pierson, E. A., and Chancey, S. T. 1998. $\mathrm{N}$-acyl-homoserine lactone-mediated gene regulation in biological control by fluorescent pseudomonads: Current knowledge and future work. Eur. J. Plant Pathol. 104:1-9.

39. Raaijmakers, J. M., Bonsall, R. F., and Weller, D. M. 1999. Effect of population density of Pseudomonas fluorescens on production of 2,4diacetylphloroglucinol in the rhizosphere of wheat. Phytopathology 89: 470-475.

40. Richardson, A. E., Djordevic, M. A., Rolfe, B. G., and Simpson, R. J. 1988. Effects of $\mathrm{pH}$, calcium and aluminum on the exudation from clover seedlings of compounds that induced the expression of nodulation genes in Rhizobium trifolii. Plant Soil 109:37-47.

41. Sambrook, J., Fritsch, E. F., and Maniatis, T. 1989. Molecular Cloning: A Laboratory Manual. 2nd ed. Cold Spring Harbor Laboratory, Cold Spring Harbor, New York.

42. Saxena, D., Flores, S., and Stotzky, G. 1999. Transgenic plants: Insecticidal toxin in root exudates from Bt corn. Nature 402:480.

43. Schnider-Keel, U., Seematter, A., Maurhofer, M., Blumer, C., Duffy, B., Gigot-Bonnefoy, C., Reimmann, C., Notz, R., Défago, G., Haas, D., and Keel, C. 2000. Autoinduction of 2,4-diacetylphloroglucinol biosynthesis in the biocontrol agent Pseudomonas fluorescens CHAO and repression by the bacterial metabolites salicylate and pyoluteorin. J. Bacteriol. 182: 1215-1225.

44. Slininger, P. J., and Jackson, M. A. 1992. Nutritional factors regulating growth and accumulation of phenazine 1-carboxylic acid by Pseudomonas fluorescens 2-79. Appl. Microbiol. Biotechnol. 37:388-392.

45. Slininger, P. J., and Shea-Wilbur, M. A. 1995. Liquid-culture pH, temperature, and carbon (not nitrogen) source regulate phenazine productivity of the take-all biocontrol agent Pseudomonas fluorescens 2-79. Appl. Microbiol. Biotechnol. 43:794-800.

46. Smith, K. P., and Goodman, R. M. 1999. Host variation for interactions with beneficial plant-associated microbes. Annu. Rev. Phytopathol. 37: 473-491.

47. Soejima, H., Sugiyama, T., and Ishihara, K. 1995. Changes in chlorophyll contents of leaves and in levels of cytokinins in root exudates during ripening of rice cultivars Nipponbare and Akenohoshi. Plant Cell Physiol. 36:1105-1114.

48. Stutz, E. W., Défago, G., and Kern, H. 1986. Naturally occurring fluorescent pseudomonads involved in suppression of black root rot of tobacco. Phytopathology 76:181-185.

49. Thomashow, L. S., and Weller, D. M. 1996. Current concepts in the use of introduced bacteria for biological control: Mechanisms and antifungal metabolites. Pages 187-235 in: Plant-Microbe Interactions. Vol. 1. G. Stacey and N. T. Keen, eds. Chapman and Hall, New York.

50. Van Overbeek, L. S., and Van Elsas, J. D. 1995. Root exudate-induced promoter activity in Pseudomonas fluorescens mutants in the wheat rhizosphere. Appl. Environ. Microbiol. 61:890-898.

51. Wood, D. W., Gong, F., Daykin, M. M., Williams, P., and Pierson, L. S., III. 1997. $\mathrm{N}$-acyl-homoserine lactone-mediated regulation of phenazine gene expression by Pseudomonas aureofaciens 30-84 in the wheat rhizosphere. J. Bacteriol. 179:7663-7670.

52. Yuan, Z., Cang, S., Matsufuji, M., Nakata, K., Nagamatsu, Y., and Yoshimoto, A. 1998. High production of pyoluteorin and 2,4-diacetylphloroglucinol by Pseudomonas fluorescens S272 grown on ethanol as a sole carbon source. J. Ferment. Bioeng. 86:559-563. 